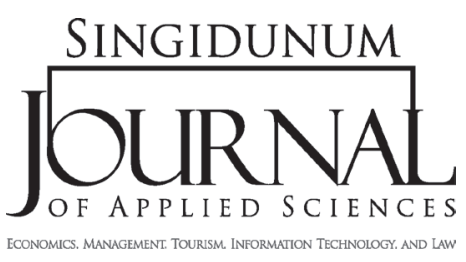

\section{ANALYSIS OF COMPETITIVENESS OF DOMESTIC ENTERPRISES ON THE GLOBAL MARKET}

\author{
Sanja Stanisavljev ${ }^{1, *}$, Dejan Đorđević ${ }^{1}$, Dragan Ćoćkalo ${ }^{1}$ \\ ${ }^{1}$ University of Novi Sad, Faculty of Engenieering, \\ Đure Đakovića Street, Zrenjanin, Serbia
}

\begin{abstract}
:
The paper analyzes the competitiveness of enterprises in Serbia, the factors that are essential primarily for their survival and then their growth on a dynamic, modern market. Lack of knowledge, obsolete equipment, inadequate use of management techniques and modern technologies lack of financial capital are some of the factors that contribute to a precarious competitive position. The World Economic Forum reports about the alarming decline of the average assessment of competitiveness, which was 3.90 in 2008 and 3.84 in 2010. Also, there was a decline in the list of competitiveness of countries in transition - from the $13^{\text {th }}$ place in 2008 to the $15^{\text {th }}$ place in 2010 .
\end{abstract}

SINGIDUNUM JOURNAL 2012, 9 (1): 1-8

ISSN 2217-8090

UDK 338:339.137.2(497.11); 339.13

Original paper/Originalni naučni rad

\section{Key words:}

competitiveness, modern business, innovation.

\section{INTRODUCTION}

Enterprises that want to succeed in the global market, need to invest significant business efforts - to monitor large, numerous and fast events, to apply new technological attainments, and to continuously learn and acquire new knowledge. The main parameter of the success of an organization is the improvement of business productivity. The struggle for higher productivity is actually a struggle for competitive advantage. Competition has become global, so modern enterprises need to appear in the market with global strategies.

Successful business in modern economy is determined by the ability of an enterprise to meet the demands of the market, to track changes which are more and more frequent and dynamic.
The globalization of world economy imposes changes in the way of business thinking in terms of accepting the fact that changes are needed permanently, and that those who do not innovate inevitably disappear from the economic scene. In such a changed economic environment, activities of an enterprise must be long-term rather than short-term oriented. Timely reaction to changes becomes the basis of successful management and training of an enterprise for successful functioning in the global market.

The global economic crisis affected the change in behaviour of enterprises when it comes to maintaining competitiveness. Most of the taken measures boiled down to reducing costs in order to maintain productivity, establishment of strategic partnerships, but again the focal point was price competitiveness, 
which may have even been neglected for a while. New business conditions demand a new understanding of competitiveness. Countries in transition were also affected by the economic crisis, primarily on the basis of the withdrawal of high-quality investors, or freezing current investments. Insufficient competitiveness of domestic enterprises again came to the fore in terms of effects of the global economic crisis (Seifert et al., 2008). On the other hand, it is evident that the global economic crisis did not have much impact on the development of newly industrialized countries such as China, India, Brazil, Indonesia, etc.

\section{COMPETITIVENESS AND CONTEMPORARY BUSINESS}

Contemporary business is characterized by the globalization of markets, the speed of numerous changes, fast rate of technological changes, development of technology and information technology. In order to achieve success in the market, an enterprise must possess competitive advantage in the form of lower costs or product differentiation. Also, it is necessary to achieve competitive advantage through a long-term provision of high-quality goods and services and continuous innovation of products and services. Companies are forced to continuously improve business productivity, which is based on improving the productivity of knowledge of employees, in order to achieve business excellence and world-class products and services. It further includes building new forms of management of an organization, as well as the implementation of the most modern management techniques.

Today, numerous and very different definitions of competitiveness are found in reference books, in which a clear distinction between macro and micro competitiveness is often made. Competitiveness is a contribution of a kind to gross domestic product (GDP), standards of living, employment. Contemporary consideration of issues of competitiveness also involves the differentiation of two basic concepts. One is micro competitiveness - the competitiveness of an enterprise is based on relative prices and product quality, compared to the offer of other vendors, and the other concept is macro competitiveness, whose basis is built in such a manner that a country, by increasing exports of goods and services, covers the imports and, at the same time, reaches the factor incomes, with which it can compete with the incomes of the countries with which foreign trade is predominantly conducted (Presnall, 2003). Also, competitiveness can be analyzed from the perspective of two indexes: Index of Competitive Growth (GCI) and the Microeconomic Competitiveness Index (MICI). GCI is composed of the technology index, public institutions index and the macroeconomic environment index and measures the capacity of the national economy to achieve stable economic growth over the medium-term period and takes into account the level of income per capita. The MICI is a weighted average of two subindexes: one reflects the degree of development of strategies and operational practices of companies, and the other refers to the quality of local business coditions.

In the modern business conditions, enterprises can survive only if they provide marketing their products in a particular market or market segment. Since a large number of enterprises fight for the same consumer group, an intense competitive struggle takes place in the market. When two or more enterprises compete in the same market (Grant, 2005), one enterprise has a competitive advantage if it achieves higher profits than the others. Therefore, the competitive advantage is the ability of enterprises to outperform their rivals in achieving the primary goal.

According to Kotler (2004), every new technology is a force for creative destruction - the greatest danger for any company is not other companies, but the application of new technological solutions. Kotler says: "Horse carriages were not defeated by better horse carriages, but carriages without a horse. Transistors harmed the industry of vacuum tubes, photocopying harmed the industry of carbon paper, and digital cameras harmed the photo-film production". The essence of new technologies is to increase business productivity which improves the competitiveness of enterprises.

Competitiveness is defined as a set of institutions, policies and factors that determine the level of productivity of a country. The level of productivity, on the other hand, determines the sustainable level of prosperity which can be created by an economy. The more competitive an economy is, the more competent will it be to produce a higher level of income to its citizens. The level of productivity determines the rate of return and since the rate of return is the key to the economic growth, the economy that achieves faster medium-term and long-term growth is more competitive (Sala-i-Martin et al., 2007). The concept of competitiveness thus involves both static 
as well as dynamic components: although the productivity of a country is clearly determined by its ability to maintain a high level of income, at the same time it is one of the key determinants of the return made by investments.

Porter (2008) suggests that in the competitive struggle for national prosperity it is less important which branch a nation competes in, but it is far more important how it competes.

In the developed world, an association of the term competitiveness is the growth formula. Being competitive means being successful and growing and the prerequisites are the efficiency of the enterprise and its high productivity. The term competitiveness used to refer exclusively to enterprises and their products and services. However, with the strong growth of internationalization of enterprises and the economy as a whole, problems of international competitiveness are more and more present, of particular companies or their products and services, as well as of some narrower or wider sectors, but also economy as a whole (Kovačević, 2002).

The competitiveness of enterprises can be seen as the core of success or failure of a single enterprise (Train and Egbu, 2006).

\section{COMPETITIVENESS OF SERBIA}

When we talk about competitiveness, Serbia is in an unenviable position. Aggravating circumstances that stand in the way of inclusion of local enterprises in the global economy trends are primarily related to their long absence from the global market as a result of the international isolation of our country. In such circumstances, an inadequate treatment of foreign markets in the strategy of growth and development of our company occurred.
The results of one survey, which analyzed the competitiveness of domestic enterprises (May-June 2007, the market of the Republic of Serbia), indicate the following when it comes to the assessment of the level of innovativeness of local organizations: a high level of innovativeness $-14.29 \%$, a satisfactory level of innovativeness - 51\%, an average level of innovativeness - $24.49 \%$, the low level of innovativeness $10.22 \%$. As the main obstacles in the development of competitiveness of domestic enterprises the analyzed executives have mentioned: the lack of knowledge $24.8 \%$, obsolete equipment and technologies $-24.1 \%$, inadequate use of modern methods and techniques of management $-16.54 \%$, the lack of stimulating business environment $-8.27 \%$, the lack of financial capital $-8.27 \%$, business internationalization of local enterprises $-2.34 \%$. As the necessary elements for the development of competitiveness of local enterprises the analyzed executives observed: continuous improvement of knowledge of the management and employees $-20.74 \%$, the standardization of the quality of operations - $20 \%$, development of entrepreneurial culture in the business environment $-17 \%$, investment in the development of national brands $14.8 \%$, the development of the concept of corporate entrepreneurship of an organization $-8.88 \%$ (Alderson, 2009).

According to the global competitiveness index of the World Economic Forum, Serbia took the $96^{\text {th }}$ place at the end of 2010, which represents a fall of 3 places compared to 2009 when it was in $93^{\text {rd }}$ place out of 133 countries for which the index was monitored. Compared to 2008 , when it took the $85^{\text {th }}$ place, according to the competitiveness index, Serbia dropped by eight places in 2009, and from 2008 to 2010 by even 11 places. Serbia's ranking in global competitiveness level 2008-2010 is shown in Chart 1. The overall index of competitiveness of Serbia is also shown in Table 1, column Rank CD.

\section{Global competitiveness of Serbia}

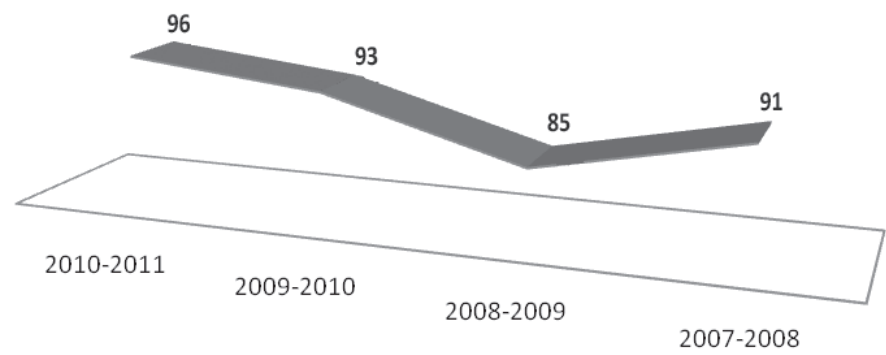

Chart 1: Rank of Serbia, adapted according to the global competitiveness index of the World Economic Forum. 
According to the Table 1, by competitiveness, Serbia is in the penultimate $15^{\text {th }}$ place of 16 transition countries of Central and Southeastern Europe, ahead of Bosnia and Herzegovina. Since 2008, Serbia lost its position with the fall of the average mark of competitiveness from 3.90 in 2008 to 3.84 in
2010. Also, it dropped in the list of competitiveness of transition countries from the $13^{\text {th }}$ place in 2008 to the $15^{\text {th }}$ in 2010 . Serbia was overtaken by Macedonia and Albania in the list, and the same might happen with Bosnia and Herzegovina which threatens to overtake it.

\begin{tabular}{|c|c|c|c|c|c|c|c|c|c|}
\hline & \multicolumn{3}{|c|}{2008} & \multicolumn{3}{|c|}{2009} & \multicolumn{3}{|c|}{2010} \\
\hline & Rank - CD & Rank - TZ & Index & Rank - CD & Rank - TZ & Index & Rank - CD & Rank - TZ & Index \\
\hline Estonia & 32 & 1 & 4.67 & 35 & 2 & 4.56 & 33 & 1 & 4.61 \\
\hline Czech Republic & 33 & 2 & 4.62 & 31 & 1 & 4.67 & 36 & 2 & 4.57 \\
\hline Poland & 53 & 6 & 4.28 & 46 & 4 & 4.33 & 39 & 3 & 4.51 \\
\hline Slovenia & 42 & 3 & 4.50 & 37 & 3 & 4.55 & 45 & 4 & 4.42 \\
\hline Lithuania & 44 & 4 & 4.45 & 53 & 6 & 4.30 & 47 & 5 & 4.38 \\
\hline Montenegro & 65 & 10 & 4.11 & 62 & 8 & 4.16 & 49 & 6 & 4.36 \\
\hline Hungary & 62 & 9 & 4.22 & 58 & 7 & 4.22 & 52 & 7 & 4.33 \\
\hline Slovakia & 46 & 5 & 4.40 & 47 & 5 & 4.31 & 60 & 8 & 4.25 \\
\hline Romania & 68 & 11 & 4.10 & 64 & 9 & 4.11 & 67 & 9 & 4.16 \\
\hline Latvia & 54 & 7 & 4.26 & 68 & 10 & 4.06 & 70 & 10 & 4.14 \\
\hline Bulgaria & 76 & 12 & 4.03 & 76 & 12 & 4.02 & 71 & 11 & 4.13 \\
\hline Croatia & 61 & 8 & 4.22 & 72 & 11 & 4.03 & 77 & 12 & 4.04 \\
\hline Macedonia & 89 & 14 & 3.87 & 84 & 13 & 3.95 & 79 & 13 & 4.02 \\
\hline Albania & 108 & 16 & 3.55 & 96 & 15 & 3.72 & 88 & 14 & 3.94 \\
\hline Serbia & 85 & 13 & 3.90 & 93 & 14 & 3.77 & 96 & 15 & 3.84 \\
\hline Bosnia and Herzegovina & 107 & 15 & 3.56 & 109 & 16 & 3.53 & 102 & 16 & 3.70 \\
\hline Average & 64.1 & 8.5 & 4.17 & 64.4 & 8.5 & 4.14 & 63.2 & 8.5 & 4.21 \\
\hline Median & 61.5 & 8.5 & 4.22 & 63.0 & 8.5 & 4.14 & 63.5 & 8.5 & 4.21 \\
\hline
\end{tabular}

Table 1: Competitiveness of national economies of countries in transition.

Source: Potrer and Schwab (2009)

$\mathrm{CD}$ - rank compared to all countries; TZ - rank in relation to the transition countries

Sixteen transition countries of Central and Southeastern Europe, being observed at the average level, maintained the competitiveness at the same level in the period of the global economic crisis effects. Development of competitiveness in these countries is uneven, some countries reduce the competitiveness as a result of the negative effects of the crisis, others stagnate, and others use the existing conditions for improvement of competitiveness and thereby achieve strong requirements for the growth and development of their economies in the post-transition period.

According to the methodology of the World Economic Forum there are 12 columns of competition, namely:
1. institutions,

2. infrastructure,

3. macroeconomic stability,

4. health and primary education,

5. higher education and training,

6. goods market efficiency,

7. labour market efficiency,

8. development and efficiency of financial markets,

9. technological level,

10. market size,

11. business performance of enterprises,

12. innovations. 
The first four columns define the basic requirements and are associated with factors stimulating economy. Columns 5-10 show increased efficiency, so they are the key to the economy by mobile efficiency. The third group of columns (11 and 12) refers to innovations and business, and it is the key to the innovation-driven economy.

Analyzing Table 2, observed in groups of factors of competitiveness in the period 2008-2010, we see that Serbia's competitiveness deteriorated in most other factors apart from infrastructure, which recorded growth in 2010 of $25.9 \%$ compared to 2008 , health care and primary education, which recorded growth of $3.4 \%$ and higher education and training with the growth of $2.6 \%$. The largest drop in year 2010 compared to 2008 is recorded in macroeconomic stability, which, seen as a competitive factor, dropped from the $86^{\text {th }}$ place in 2008 to the $109^{\text {th }}$ place in 2010, which represents a negative growth, i.e. a decline of $14.9 \%$.

\begin{tabular}{|c|c|c|c|c|c|c|c|c|}
\hline & \multicolumn{2}{|c|}{2008} & \multicolumn{2}{|c|}{2009} & \multicolumn{2}{|c|}{2010} & \multicolumn{2}{|c|}{ Growth assessment } \\
\hline & $\begin{array}{l}\text { Rank } \\
\text { (of 134) }\end{array}$ & $\begin{array}{l}\text { Score } \\
(1-7)\end{array}$ & $\begin{array}{l}\text { Rank } \\
\text { (of 133) }\end{array}$ & $\begin{array}{l}\text { Score } \\
(1-7)\end{array}$ & $\begin{array}{l}\text { Rank } \\
\text { (of 139) }\end{array}$ & $\begin{array}{l}\text { Score } \\
(1-7)\end{array}$ & $2010 / 2009$ & $2010 / 2008$ \\
\hline Institutions & 108 & 3.4 & 110 & 3.2 & 120 & 3.2 & $0.0 \%$ & $-5.9 \%$ \\
\hline Infrastructure & 102 & 2.7 & 107 & 2.8 & 93 & 3.4 & $21.4 \%$ & $25.9 \%$ \\
\hline Macroeconomic stability & 86 & 4,7 & 111 & 3.9 & 109 & 4.0 & $2.6 \%$ & $-14.9 \%$ \\
\hline Health and primary education & 46 & 5.8 & 46 & 5.7 & 50 & 6.0 & $5.3 \%$ & $3.4 \%$ \\
\hline Higher education and training & 70 & 3.9 & 76 & 3.8 & 74 & 4.0 & $5.3 \%$ & $2.6 \%$ \\
\hline Good markets efficiency & 115 & 3.7 & 112 & 3.7 & 125 & 3.6 & $-2.7 \%$ & $-2.7 \%$ \\
\hline Labour markets efficiency & 66 & 4.4 & 85 & 4.2 & 102 & 4.1 & $-2.4 \%$ & $-6.8 \%$ \\
\hline $\begin{array}{l}\text { Development and efficiency of } \\
\text { financial markets }\end{array}$ & 89 & 3.9 & 92 & 3.9 & 94 & 3.8 & $-2.6 \%$ & $-2.6 \%$ \\
\hline Technological level & 61 & 3.5 & 78 & 3.4 & 80 & 3.4 & $0.0 \%$ & $-2.9 \%$ \\
\hline Market size & 65 & 3.6 & 67 & 3.7 & 72 & 3.6 & $-2.7 \%$ & $0.0 \%$ \\
\hline Sophistication of business & 100 & 3.5 & 102 & 3.4 & 125 & 3.2 & $-5.9 \%$ & $-8.6 \%$ \\
\hline Innovations & 70 & 3.1 & 80 & 3.0 & 88 & 2.9 & $-3.3 \%$ & $-6.5 \%$ \\
\hline
\end{tabular}

Table 2: Serbia's competitiveness in groups of factors of competitiveness.

Source: Potrer and Schwab (2009)

According to Đuričin and Petraković (2003) new competitiveness is a combination of adequate strategy and high productivity. In addition, productivity is the result of greater efficiency, with the adequate strategy, a temporary monopoly based on low cost or differentiation is converted into a permanent monopoly based on innovation.

The previous table shows a worrying fact that in Serbia innovation, as a factor for achieving competitiveness and survival of the modern organization, recorded a negative growth of $6.5 \%$ or a fall from the $70^{\text {th }}$ place in 2008 to the $88^{\text {th }}$ place in 2010 .
The Serbian government has recognized the importance of innovation for the increase of competitiveness of the domestic economy. The objectives of the National Strategy for Economic Development of Serbia 2006-2012 are:

- encouraging research and developmental projects aimed at the implementation of new and better technologies in industry;

- continuous education process and implementation of innovations with the aim of increasing the level of adjustment to market changes. 


\begin{tabular}{|c|c|c|c|}
\hline \multicolumn{2}{|l|}{ THE WORST } & \multicolumn{2}{|l|}{ THE BEST } \\
\hline Factor & Rank & Factor & Rank \\
\hline Degree of dominance in the market & 138 & Index of rights protection & 20 \\
\hline Effectiveness of antitrust policy & 137 & Use of broadband Internet & 30 \\
\hline Protection of minority shareholders & 137 & Time required to start a business & 45 \\
\hline Brain drain & 136 & Total Tax Rate & 46 \\
\hline Cooperation in labour-employers relations & 135 & Dismissal costs & 47 \\
\hline Effectiveness of corporative management & 134 & $\begin{array}{l}\text { Quality of mathematical and scientific } \\
\text { education }\end{array}$ & 48 \\
\hline Application of technology in enterprises & 134 & Enrolment in tertiary education & 49 \\
\hline Nature of comparative advantage & 133 & Height of public debt & 53 \\
\hline $\begin{array}{l}\text { Efficiency of legal framework to resolve } \\
\text { disputes }\end{array}$ & 132 & Number of Internet users & 54 \\
\hline $\begin{array}{l}\text { National savings rate / load control / intensity } \\
\text { of competition / customer sophistication }\end{array}$ & 131 & Quality of scientific research institutions & 56 \\
\hline
\end{tabular}

Table 3: The best and the worst factors of the competitiveness of Serbian economy.

Source: Potrer and Schwab (2009)

The fact, that for the period 2007-2013 all EU member states have responded to the call for more investment in innovation and have submitted 455 programs, also speaks about innovation as a key factor for achieving competitiveness. EU investments for innovation in the period 2007-2013 amount to more than $€ 85$ billion.

Table 3 provides an overview of the best and the worst factors of the competitiveness of Serbian economy.

Among the worst factors of competitiveness is the degree of dominance in the market which is ranked in the $138^{\text {th }}$ place, the effectiveness of antitrust policy and protection of minority shareholders who are in the $137^{\text {th }}$ place. The best rated factors of competitiveness of Serbian economy are the rights protection index in the $20^{\text {th }}$ place and the use of broadband Internet in the $30^{\text {th }}$.

According to the World Economic Forum (Alderson, 2009) report, Serbia is in the second phase, called efficiency-driven or a phase of competitiveness driven by efficiency of use of production factors (in addition to Albania, Bulgaria, Macedonia and Montenegro). When it comes to competitive phases in which a country is, we distinguish between fac- tor-driven, efficiency-driven and innovative-driven competitiveness. Every country underwent each of these stages in its development and definitely started with the competitiveness based on the supply with production factors (land, manpower, etc.) through investment-driven competitiveness, which is based on the efficiency which available production factors benefit from (labour, capital, etc.) to innovationdriven competitiveness. Slovenia is the only country in the region which is in the phase of innovationdriven economic development, the phase when the conditions themselves create technologies.

Serbia has all the prerequisites to become one of the globally competitive regions in the near future, along with other Western Balkan countries, provided that local entrepreneurs change their business philosophy most urgently. Owners of capital and executive management are the ones who need to establish new elements of competitiveness in domestic enterprises. It is necessary to abandon obsolete policies and management techniques and to adopt modern management techniques, as well as to learn from the experience of global leaders, as well as companies coming from newly industrialized countries, and which are extremely successful in the global market. 


\section{CONCLUSION}

The current market situation characterized by intense competitive struggle and rapid changes in the environment are the reason for the appearance of a growing number of companies facing the problem of stagnation and dissatisfaction in the business. In this millennium, it is clear that only those companies which are able to adapt and change quickly will succeed.

Local enterprises during the last ten years have been insufficiently competitive in the international market, and the effects of the global economic crisis have only reinforced the issue of poor competitiveness of local enterprises. Competitors of local enterprises are not only enterprises from developed, mainly EU countries, but also from newly industrialized countries such as China, India, Brazil, Mexico, Turkey, etc. In the modern business environment, enterprises are forced to accept the improved market philosophy.

Improvement of the business of domestic enterprises must be based on the application of management techniques that support competitiveness, innovation and flexibility, as well as on the emergency improvement of knowledge of the employees, especially the executive management. The degree of business performance of an organization can only be achieved on the basis of improving the productivity of all key resources of the business and existing levels of innovation. In this sense, innovation and development of management knowledge and skills of local managers are some of the key points for successful restructuring of the domestic economy. Special attention must be directed to the implementation of new approaches to management, both in conceptual and in organizational terms.

Without the improvement of factor conditions, including primarily the infrastructure and institutions, the promotion of educational and innovative infrastructure and capital markets and the financial system, Serbia will not be able to improve its unenviable competitive position.

When it comes to competitiveness, the world economy does not hold a zero sum game. It allows every country to promote its prosperity, if it achieves the growth of productivity and competitiveness, regardless of the growth or decline in the competitiveness of other countries. This has particularly been facilitated recently by the globalization process, which has, on the one hand, enabled prosperity to those who increase competitiveness, but on the other hand, at the same time, it has relatively increased costs to those with low productivity (Porter and Ketels, 2007).

Once acquired competitive advantage can be maintained only by making improvements. Since competitive advantage is achieved at the level of companies, there are two prerequisites for maintaining an acquired competitive advantage: the global approach and the ability of companies to make their once gained competitive advantage obsolete.

It is extremely important for Serbia to create preconditions for the innovation-driven competitive economy phase, for only those countries, enterprises, which are innovative and flexible, will survive and improve the business competitiveness. Some of the solutions are focused on micro competitiveness, small and medium enterprises, and the formation of clusters.

\section{REFERENCES}

Alderson, M. (2009) HELP projekat za konkurentnost u srednjoj i istočnoj Evropi. CESS magazine, a magazine for Regional Policy and Development. 16 (1), 37-39.

Grant, R. (2005) Contemporary Strategy Analysis Concepts, Techniques, Applications. Georgetown University: Blackwell Publishing.

Kotler, F. (2004) Marketing od A do Z. Novi Sad: Adižes. (in Serbian)

Kovačević, M. (2002) Međunarodna trgovina. Belgrade: Faculty of Economy, University of Belgrade. (in Serbian)

Porter, M.E. (2008) Regional Competitiveness. The Summit for American Prosperity. 11-12 June 2008 Washington.

Porter, M.E., Ketels, C. (2007) Competitiveness in the Global Economy: USA's Position. Globalization Council. 27 April 2007 Stockholm.

Potrer, M.E., Schwab, C. (2009) The Global Competitiveness Report 2009-2010. Geneva: The World Economic Forum.

Presnall, A. (2003) Competitiveness of Serbia in 2003. New York: Jefferson Institute.

Sala-i-Martin, X., Blanke, J., Hanouz, M.D., Geiger, T., Mia I., Paua, F. (2007) The Global Competitiveness Index: Measuring the Productive Potential of Nations. In: Porter, M.E., Sala-i-Martin, X., Schwab, C. (eds) The Global Competitiveness Report 2007-2008. Basingstoke: Palgrave Macmillan.

Seifert, M., Besić, C., Petrović, N. (2008) The role of corporate in the process of improving the quality of operations of domestic companies. International Conference JUSK ICQ 08. 1-4 June 2008 Belgrade. 
Train, A., Egbu, C. (2006) Maximising the Impact of Knowledge for Innovation. Gaining Competitive Advantage, Construction and Building Research Conference (COBRA). 7-8 September 2006 London.
Đuričin, D. (2005) The strategy for Serbian Competitiveness 2005-2010. Business Forum. 7-9 March 2005 Kopaonik.

\section{ANALIZA KONKURENTNOSTI DOMAĆIH PREDUZEĆA NA GLOBALNOM TRŽIŠTU}

\section{Rezime:}

U radu se analizira konkurentnost preduzeća u Srbiji, faktori koji su neophodni prevashodno za opstanak, a zatim i njen rast na dinamičnom, savremenom tržištu. Nedostatak znanja, zastarela oprema, neadekvatna upotreba metoda menadžmenta i savremenih tehnologija, nedostatak finansijskog kapitala,samo su neki od faktora koji doprinose nezavidnoj konkurentskoj poziciji. Izveštaj svetskog ekonomskog foruma govori o zabrinjavajućem padu prosečne ocene konkurentnosti koja je bila 3,90 u 2008., a 3,84 u 2010. godini. Takođe se beleži pad na listi konkurentnosti tranzicionih zemalja sa 13. mesta u 2008 godini na 15. mesto u 2010. godini.

\section{Ključne reči:}

konkurentnost, savremeno poslovanje, inovativnost.

Received: July 12th, 2011 Correction: September 3th, 2011 Accepted: November 11th, 2011 